\title{
Rewriting Israeli History: New Historians and Critical Sociologists
}

\author{
ADAM COMAN*
}

\author{
Revize dějin Izraele: Noví historikové a kritičtí sociologové
}

\begin{abstract}
The New Historians and Critical Sociologists were two groups of thinkers who emerged in Israel during the 1980s, strongly criticizing Israeli history and society. Coming from diverse backgrounds and using different methodologies, nonetheless they all shared a highly critical approach towards mainstream historians and sociologists, and, more importantly, towards key moments and issues in Israel's history. These thinkers blamed the Zionist establishment for ignoring the distress of the European Jews during the Holocaust, committing war crimes against the Arab population during the 1948 War, and abusing immigrants in the years after the state's independence. These claims raised passionate debates between mainstream and critical scholars, which strongly affected Israeli society. This paper examines the processes that led to the emergence of these thinkers, the novelty of their historical narratives and interpretations, and analyzes the specific terminology they employed, as well as their opponents' criticisms, which their research provoked.
\end{abstract}

Keywords: Israel; Israeli-Palestinian conflict; historiography; sociology; revisionist history

DOI: $10.14712 / 23363525.2018 .41$

\section{Introduction}

Up until the 1980's, Israeli historiography and sociology reflected, by and large, Israel's mainstream, uncritical, historical and sociological narratives concerning the making of Israel and the Arab-Israeli conflict. The essence of this narrative runs more or less as follows: the 19th century saw a Jewish national revival in Europe, which sought to create a Jewish State in the Land of Israel. However, the land was occupied first by the Ottomans and since 1917 by the British, who objected to the Jews' resettlement in their motherland. Nonetheless, the growing antisemitism in Europe and the Zionist efforts propelled the British government to support the idea of a Jewish "national home," in the form of the Balfour Declaration (1917), and the Peel Commission (1936). While the Zionists sought to create a progressive and egalitarian society in Israel, the Arabs were growing increasingly hostile towards the Zionists, violently attacking them and sabotaging their efforts. Before and during the Holocaust, the Zionist organization did all it could to save the European Jews, exercising both diplomatic and military efforts, such as the parachuting of Zionist fighters behind enemy lines. In 1947, following World War II, the United Nations acknowledged the Jews' right for their own country. Following Israel's declaration of independence, it was attacked on all frontiers by hostile Arab armies. During the war, Palestinians fled

Adam Coman - Ph.D. student in the Historical Sociology department, Faculty of Humanities, Charles University. U Křriže 8, 15800 Praha 5. E-mail: adam.coman@gmail.com. 
Israel to neighboring territories under their leaders' commands, and in spite of Israel's attempts to convince them to stay. Despite its inferior military standing, the small Israeli army managed to vanquish the stronger, plentiful Arab armies. Following Israel's independence and victory, Holocaust survivors and Jews from Muslim countries, immigrated to Israel and helped build the new state.

The 1980's saw the emergence of several Israeli historians and sociologists who challenged this narrative. Proclaiming themselves "new historians" and "critical sociologists," these thinkers wanted to bring to light and public attention topics which were either unknown to or undiscussed by the dominant historians, and the general Israeli public. In this paper they will be referred to as the Critical Historians, while the "old" historians and "institutional" sociologists will be referred to as "old" historians.

The Critical Historians challenged this narrative on four main fronts: first and foremost, they discussed the maltreatment of Palestinian civilians in the 1948 War. Using previously classified documents made available by the opening of state archives, the Critical Historians showed that the Israeli army was responsible for several massacres and deportations of Palestinians. Second, they compared Zionism with colonialism, suggesting the Zionists, like the American Puritans, and French colonialists, exploited and disinherited the local population. Third, they criticized the Zionist elite for ignoring the distress of the European Jews before and during the Holocaust, and for mistreating the survivors and Jewish immigrants from Muslim countries, who came to Israel after 1948. Finally, they aspired to replace the "old" historians' terminology, which they considered inherently justified Zionism, with a new terminology, which would reflect the neutral or negative motives and consequences of the Zionists actions. The Critical Historians' research, it should be noted, was intended not only to create an academic debate, but moreover, to influence and change Israeli national memory and collective consciousness.

This paper explores the different arguments and methodologies of the Critical Historians, focusing on theories of hegemony, colonialism, and the Palestinians' place in the Israeli-Palestinian conflict. Considering the four main topics the Critical Historians targeted, the final part of the paper explores the main arguments of the "old" historians and sociologists who criticized and opposed the Critical Historians.

\section{The Emergence of the Critical Historians}

In order to better evaluate the Critical Historians' research, it is important to understand the social, political, and historical circumstances of their emergence.

The term "new historians" was originally coined in a 1988 paper by Benny Morris to describe himself, Avi Shlaim, Ilan Pappé, and Simha Flapan. According to Morris, the main reason for the Critical Historians' emergence was the opening of state archives. Throughout the 1980s the Israeli government was declassifying "hundreds of thousands, perhaps millions" of papers [Morris 2007: 14-15], from the years 1947-1956, including Foreign Ministry, Defense Ministry, and IDF documents. These documents played the main role in Morris's The Birth of the Palestinian Refugee Problem which exposed expulsions and massacres committed by the Israeli military and para-military forces. The book was one of the first Critical Historiographies to be published in Hebrew (most early works were written in English), and therefore played a central role in the early part of the historians' debate. 
Morris also explained the Critical Historians' emergence through the historians' sociological profile - all were born around 1948. Unlike (literally) older historians, who had participated in Israel's foundation, experiencing the war at first hand, the Critical Historians judged Israeli history from a more detached and analytical standpoint, especially in light of the 1982 Lebanon War, which many Israelis saw not only as an extremely bloody war, but also as the first senseless war instigated by Israel [Morris 2007: 14-15].

Aside from these technical reasons, other factors also influenced their emergence. Some scholars, such as sociologists Baruch Kimmerling, Uri Ram, and Gershon Shafir were heavily influenced by the international academic climate of the 1970's-80's. Throughout the Western world this was the high tide of postmodern theories and multi-narrative histories. Influenced by these theories, many Israeli academics were eager to implement them in their own immediate environment [Ram 2006: 247; Taub 1997: 232]. These sociologists introduced several new concepts into the discourse on Israeli history, most importantly Zionism as colonialism, and Mapai's hegemonic rule which excluded other minority groups from Israel's political and social nerve center.

Another important role in the Critical Historians' crystallization was played by social and political events which, as of the Six Day War (1967), and the occupation of the Palestinian territories, pushed Israelis to "soul-search" their past, present, and future. These events include: the 1973 Arab-Israeli War; the reawakening of the Palestinian national movement in the 1970s; the 1977 rise to power of the Right-wing Likud at the expense of the socialist-left Ma'arakh for the first time in Israeli history; the 1982 Lebanon War; and finally, the outbreak of the First Intifada in 1987.

These events both affected and reflected Israel's self-perception and self-awareness [Kimmerling 2001: 23]. The Critical Historians' emergence represented what many have termed a "maturing" process of Israeli society, which entailed a confrontation with Israel's less-heroic moments on the one hand [Friling 2003], and a rebellion against the established academia on the other. Israeli society, like its historians was becoming disillusioned with past myths and conceptions; reappraising Israel's part in the Arab-Israeli conflict; demythologizing Israel's founders; and cautiously readjusting Israel's political and social vision. Politically, this process was symbolized by the growing comprehension that Israel should reach some sort of understanding with its neighbors - a realization which culminated in the 1993 Oslo Accords led by the far-from-dovish Yitzhak Rabin. Raising strong objections from various parts of society, the Oslo Accords nonetheless represented Israel's maturation, acceptance of responsibility, and willingness to participate in creating a new regional reality.

\section{Terminology: Demythologizing Israeli Myths}

One of the major issues the Critical Historians attacked was what they considered the "old" historians' part in "mythologizing" Israeli history [Segev 1998: v]. This mythologization, they argued, was accomplished not only by constructing a unique narrative and depicting specific events, such as the heroism and exceptional morality of the Israeli soldiers, but more so, by using a specific terminology which justified a priori the Zionist cause [Lissak 2007: 180]. Thus, by using the terms eretz Israel (land of Israel) when describing Palestine under Ottoman and British rule, the geographical entity was depicted 
as belonging to the Jewish people throughout history. The term aliyah ("ascent") conveys Jewish immigration to Palestine/Israel in a positive way, while yerida ("descent"), emigration from it, carries a negative undertone. On the other hand, the Arabs' and Palestinians' rebellions against the British mandate and the Jewish settlement were called meora'ot (literally "events"), an abstract term which conceals the actual causes which led to these rebellions [Gelber 2007: 463]. These are just a few examples of how Israeli history came to possess a mythological aura, connecting contemporary Zionists all the way to the biblical Hebrews, thereby establishing the Jews' moral and rightful claim to the State of Israel both in territory, and in statehood.

In order to counter this subjective historical description, one of the main tasks the Critical Historians undertook was revising historical and sociological terminology, mainly by replacing positive terminology with neutral or negative terminology: the War of Independence, was substituted by the 1948 War, or the First Arab-Israeli War; instead of aliyah, Jews merely immigrated to Israel, or worse, they colonized it; the meora'ot were now Arab rebellions; eretz Israel became Palestine; the generic term Arabs was replaced with Palestinians, etc. [Lissak 2007: 180].

The Critical Historians, however, were not content only with revising terminology, but also took to task classical Zionist terms for their destructive implications. "The negation of the diaspora," for example, which designated Israel as the only home for the Jews, caused the Zionist settlement to largely ignore the distress of the European Jews before and during the Holocaust [Segev 1991: 404]. One of the Zionists' aims, the creation of "the new Jew," which signified the revival of Jewish identity and nationhood, possessed fascist roots, and brought along feelings of indifference and contempt towards the European Jews by the Jewish settlement in Palestine [Segev 2001: 23-24].

Finally, some terms, especially colonization and hegemony, pushed for new and extended research on Zionism as colonialism [Pappé 1997: 346], and the privileged hegemonic Mapai party and its exclusion of non-hegemonic and minority identities [Ram 1993: 7].

Considering the mainstream historical narrative mentioned in the introduction, the Critical Historians wrote about a Zionist elite which began colonizing Palestine in the 19th century, exploiting the local population for labor on the one hand, while depriving it of its land, backed and supported by the British Mandate. The Zionist elite ignored the distress of the European Jews during the World War II, seeing them as bygone relics of a decadent world. During the 1948 War, the Israeli forces, better equipped and more organized than the Arab armies, committed war crimes against Palestinian civilians, and deported them under government orders. After the War, Holocaust survivors and Jews from Muslim countries were propelled to immigrate to Israel, where they were accepted with disdain and contempt, excluded from the social and political nerve centers.

\section{Zionism as Colonialism}

At first glance, the similarity between the Zionist movement and other colonial movements is self-evident: the Zionist movement was formed by white European men during the 19th century, and like previous religious, national, and expansionist movements, sought religious revival in Palestine [Pappé 1997: 357-358]. Initial attempts by the Zionists to rely on their own labor and resources proved futile, and they began seeking help 
through overseas donations [Shafir 1993: 110]. In addition, their early infatuation with and admiration of the indigenous' way of life quickly gave way to embittered hostility. Consequently the Zionists began to condescend and exploit the indigenous population, while robbing it of its land and resources [ibid.: 110-111]. Finally, the survival of the Zionist settlement and the formation of the State of Israel would not be possible without the support of the British Empire, which allied with the World Zionist Organization, and "which both opened up and secured the country to Jewish immigration and land purchase" [Kimmerling 2001a: 90].

Postcolonial theories inherently share some common factors such as the division of society into exploiting colonizers and exploited indigenous victims, as well as the focus on the colonizers' condescending view of the natives, which in the Middle Eastern context is associated with Edward Said's "orientalism." Proponents of the "colonialist Zionism" paradigm frequently claim that Zionist colonization was the main trigger for Arab and Palestinian hostility towards the Zionists, and that consequently the postcolonial prism is the most suitable for understanding the history of the Israeli-Palestinian conflict [Shafir 1993: 104].

Nonetheless, the uniqueness of the Zionist movement compared to other colonialist movements is undeniable. To name just a few differences: Zionism was a national movement which sought to secularize biblical symbols, unlike the puritans of North America; the Zionists did not act as an extension of a country or a church, therefore they did not exploit the land's resources for an overseas base, nor did they receive organized and stable support from a strong administrative body; finally, unlike other colonial movements who were predominantly "pulled" to distant colonies, the Zionists were equally "pushed" from Europe by the pogroms in East Europe and rising antisemitism [Bareli 2003: 305].

In face of these disparities, supporters of colonialist interpretations of Zionism have had to justify the "colonialist Zionism" narrative, and consequently there are several postcolonial theories concerning the Zionist movement.

One of the main methods for constructing a colonialist narrative of Zionism, is finding a historical "parallel" of the Zionist movement, such as the American Puritans, or German and French colonialism, and pointing out similarities in various colonial aspects, such as motives for colonization, methods of expansion, external supporters of colonization, and the relations between the colonizers and the indigenous population. Thus, Pappé recognized similarities between the Zionists and the idealist-agrarian Basel Mission which attempted to build a colony in Palestine [Pappé 1997]. Pappé found similarities between the movements mainly in terms of discourse (the "return" to the promised land); symbolism (the "ideal village"); historical context (both phenomena took place against the background of rural industrialization); education (hostility towards Islam); gradual corrosion of ideals, etc. [ibid.: 358-362]. Pappé did mention some differences between the movements, mainly the Zionists' dependence on British goodwill in establishing a state, and the ultimate goal of the settlements (the Mission did not aspire for the immigration of all Christians, nor did it consider industrialization), but these were mentioned briefly, and as insignificant. Similar approaches were taken by Shlomo Sand, who found equivalences between Zionism and the Spanish Conquistadors in Latin America, and Kimmerling and Ram, who found analogies to the Puritan colonization in North America [Gelber 2007: 412-413]. 
Gershon Shafir, one of the earliest sociologists to have used the postcolonial prism, linked Zionism to European colonialism by identifying different types of European colonialism, and assessing the similarities and differences between Zionism and various colonial types. Following the categorizations of researchers D. K. Fieldhouse and George Fredrickson, Shafir recognized four main types of colonies: occupation; mixed; plantation; and pure settlement [Shafir 1993: 106]. Shafir claimed Zionism was a mixture of plantation and pure settlement colony, notwithstanding specific characteristics it developed over the course of time. Both types represented colonies in which Europeans colonized territories for the purpose of inhabitance and exploitation of resources and land. The plantation colony is characteristic of the cotton areas in the south of the United States, where black slaves were imported from Africa for labor, while the pure settlement colony is characteristic of the north of the United States, Australia, and New Zealand, where the colonizers either deported or annihilated the local population, and both employers and employees belonged to the same ethnicity. The Zionists, Shafir argued, had to decide whether they wanted to create a plantation colony, in which the Arabs would be delegated to a lower "caste" of workers and citizens, or whether they should create a pure settlement colony, from which the Arabs would be expelled [ibid.: 108].

Shafir did acknowledge three distinctive characteristics of the Zionist movement: the second immigration wave's adoption of a pure settlement colony instead of a plantation colony; which segmented the land's economy into three: the Arab, the plantation, and the pure settlement economy, which was to become the backbone of the Israeli State's economy. Segmenting the land's market was later to serve as the basis for the partitioning of the land into the Jewish and Palestinian states [ibid.: 114].

Shafir's analysis is a typical example of the "Zionism as colonialism" paradigm. As a pioneer in using the postcolonial prism in Israel, Shafir opened the door to other postcolonial works which focused on the cultural clash between the Zionists and the Arabs, and explored various dimensions of exploitation and abuse on the Zionists' part. What is evident in Shafir's portrayal of the Zionist movement's settlement process is the use of precise terminology and rigid description, which hardly address the Zionists' ideological motives or their reasons for having emigrated from their homelands. Shafir's description is extremely technical, and gives primacy to economic considerations and actions, all but ignoring the roles played by political and social factors in the Zionist movement, and treating idealist discourse, such as "conquest of labor" as merely rhetorical, designed to promote purely functional purposes.

\section{Hegemony and Elite}

The Critical Historians have also researched two interconnected terms: "hegemony" and "elite." The Israeli use of the term hegemony is rooted in Gramsci's cultural-political theory, and was developed primarily by Kimmerling and Ram, while the term elite was developed less theoretically but more narratively, by Segev [Kimmerling 2001; Kimmerling 2001a; Ram 1997; Segev 1991; Segev 1998]. Kimmerling termed the Israeli elite AHUSALIM: an acronym standing for Ashkenazi, secular, veteran, socialist, and nationalist. According to Kimmerling, "The AHUSALIM built [Israeli] society and state, won the 1948 War, during which they expelled a considerable part of the Arabs from the State's 
territories, absorbed a massive amount of immigrants and crushed them in a cultural and political crusher in order to make them a new nation through melting pot mechanisms. The AHUSALIM were the undisputed lords of the land, at least during the first two decades" [Kimmerling 2001: 11-12].

From the Critical Historians' perspective, this elite was mainly criticized for being intolerant towards new Jewish immigrants, forcing them to comply with and adopt the previously established customs and norms; for neglecting the European Jews during the Holocaust; and for excluding non-elite groups such as the Arabs, the ultra-Orthodox, and the Sephardic Jews from the political, economic, and cultural spheres.

The first Zionist immigrants arrived to Palestine in the end of the 19th century. These immigrants created their own "social and mental 'bubble," secluding themselves from the local Arabs, while depending on them for land acquisition and labor nonetheless [Kimmerling 2001a: 90]. As of the early 1920s, the settlement sought to develop its own institutions and organizations, in order to create a sort of "state-within-state," for the purpose of administrating the Jewish settlement [Kimmerling 1993: 333].

Kimmerling identified five basic premises of the Jewish settlement, inherent to its identity: the future "Jewish commonwealth" was to be established in all or part of British Mandate Palestine, and until the community was consolidated, it would give preference to absorbing mostly young, able Zionists; the Jewish settlement was a direct continuation of the ancient biblical Jewish society; the settlement's inner and external legitimacy was given by the bible and other religious sources; Hebrew was adopted as the formal language; a hybrid calendar was created, made out of secularized religious holidays and national holidays, such as May Day [Kimmerling 2001a: 92-93].

The pre-Israeli elite established and fortified its status mainly by having succeeded in building a society out of thin air, forming a strong and efficient military force, and replacing the stereotypical weak, uprooted "diaspora Jew," with the strong, working "new Jew" - the sabra (literally: prickly pear). Excluded from the borders of the Jewish organized settlement and the future state were the Arabs, the ultra-orthodox Jews, the "old yishuv" Sephardic Jews, and the communists [Kimmerling 1993: 333-334]. Participation in the construction and modelling of the new state was possible only to those who adopted the values, ideas, and customs of the ruling elite [ibid.: 335].

The formation of the State of Israel saw the doubling of the Jewish population from 650,000 to $1,300,000$ with the arrival of immigrants from Muslim countries and Holocaust survivors on the one hand, and the decrease of the Arab population from 900,000 to fewer than 150,000 on the other [Kimmerling 2001a: 94]. The Israeli elite was both suspicious and disdainful of the new immigrants, viewing the survivors as avak adam ("human dust," i.e. wrecked people), who might take over state mechanisms. The non-European Jews, on the other hand, were viewed as "low quality" human material, stereotypically seen as aggressive, uncultured, and lazy, having come from barbaric countries which did not experience Enlightenment and modernity [ibid.: 95-96]. The Arab and Levantine culture which they brought with them was seen as a primitive threat to the Israeli culture, which was rooted in European culture and thinking. Immigrants who did not integrate into the old establishment through marriage and/or by adopting the elite's values were made to become manual workers, and were excluded from the centers of society by being located in peripheral villages and development towns [Kimmerling 1993: 336]. Their assimilation difficulties 
were ignored by the establishment, which expected only the younger immigrants and the following generations to become "true" Israelis.

The Israeli elite also feared for its political status, as the survivors, among whom there were many socialists and communists, might seek to "communize" the state, whereas the non-Europeans might align themselves with the nationalist, right-wing, Revisionists. As a result, the elite secured its status by creating a new Israeli hegemonic identity. This identity was created through a highly centralized "all-encompassing institution" and by generating a "new state civil religion, with its own cults, ceremonies, calendar, holidays and commemorations [...], first around the military, and later around the Holocaust" [Kimmerling 2001a: 96-97]. In many ways this civil religion was a reformation of the pre-Israeli settlement hegemony, revolved around the pioneers' civil religion [Ram 1996: 21].

Whereas the settlement's main ethos was collectivism, the state's was mamlachtiut, i.e. raison d'etat, the state itself. At the center of this ethos was the military, as the Israeli-Palestinian conflict was seen more and more unresolvable [Kimmerling 2008: 143]. Military service being obligatory, the military also played a crucial part in modelling the Israeli sabra. The militaristic ethos left its mark on Israeli society even after it was replaced with the Holocaust (following the Eichmann trial in 1961), and consequently Kimmerling termed Israeli society a "civilian militaristic" society, in which the entire "social nexus," both institutionally and mentally, is oriented towards a militaristic protection of society and the collective [ibid.: 141]. As a result of this mentality, groups who do not serve in the army, especially Arabs and the ultra-orthodox, are a priori excluded from mainstream Israeli experience and daily life.

Segev's criticism of the old Israeli elite was most explicitly formulated in his 1991 The Seventh Million. Segev criticized three main aspects of these relations: before, during, and after the Holocaust.

During the first years of the Nazi regime, the Zionist elite did not realize the extent of the danger German Jews were facing. Segev illustrated this problem through the story of Arthur Ruppin. Following the Nazis rise to power, Ruppin, a Zionist activist, went to Germany in order to discuss the terms of the German Jews' immigration to Palestine. "The whole of Germany was under terror, but Ruppin found it difficult to recognize the Nazis' revolution. 'Had I not known from newspapers and personal conversation to what extent the Jews' economic and political conditions had deteriorated [...] - I would not have felt it by the street's appearance, not in Berlin, in any case,' he wrote in his diary" [Segev 1991: 16]. Meeting with Professor F. K. Günther, one of the leading ideologists of Nazi racial theory, they amiably discussed the origins of the "Jewish race." Segev used Rupin's and other Zionist activists' comments and remarks in order to display the Zionists' indifference towards the German Jews, and non-Zionist Jews in general. Their main fear was that Jews leaving Germany would immigrate to places other than (future) Israel, and it was this concern which pushed them to sign the haavara (transfer) agreement with the Nazis, which enabled the Jews to transfer some of their property to Israel. In addition, the elite's Jewish Agency meticulously selected who was to immigrate. The representatives selected candidates who were closer to the Zionist cause on the one hand, and who were young and physically abler to assist the settlement on the other [ibid.: 35].

In British Palestine the immigrants suffered not only from the weather and diseases, but also from the old settlement's condescending treatment. The old settlement, made out 
of predominantly ardent ideological immigrants, felt disdain towards the Yekke (a derogatory term for the German Jews), who preferred staying in Europe, and made aliyah only out of necessity [Segev 2001: 23].

During the Holocaust, Segev claimed, the elite largely ignored the European Jews' tragedy, and instead of trying to help the European Jewry, focused on building the future state. Two of the main elements of Zionist ideology, "the negation of the diaspora" and "the new Jew" had long distanced the settlers from the European Jews. The ideal of the "new Jew" was borrowed from similar Soviet, Fascist, and Nazi ideals. The "'new Jew' was erect, brave, handsome, physically developed, enjoyed work, sports, and games, and was free in movements, and dedicated to his people and possessions" [Segev 1991: 25]. "Negating the diaspora" meant juxtaposing the "new Jew" with the "old," urban, exilic Jew. The latter was seen as a weak, uprooted, decadent remnant of a dying world, a submissive citizen of states not his, at the mercy of hostile governments and people, helpless against the occasional pogrom, while the chalutzim were reclaiming the honor of the Jewish people. The negative stereotype of the urban exilic Jew had sometimes reached classical anti-Semitic descriptions, with Jewish moneylenders described in Haaretz as "blood sucking leeches" [ibid.: 26].

For the Zionists, returning to Israel was the Jewish people's return to "normality." Deterministically, Jewish history in the diaspora was seen as meaningless in itself, whereas "connecting" to the land was important precisely because it "anchored" the nation, thus bringing it "back to history" [Raz-Krakotzkin 1993: 23]. Exilic Jews were resented precisely because by remaining in exile, they were postponing the rebirth of the Jewish people.

At the same time, the Zionist elite exhibited a cynical, realpolitik attitude towards the Holocaust. Essentially indifferent towards the European Jews, the leadership did see the war's upside: whereas the First World War secured the Balfour Declaration, the Second World War would secure the state itself [Segev 1991: 72]. This, Ben-Gurion claimed, would be the Zionists' "political conscience" during the war. The Jewish Agency's responsibility was to build a state, not to save "one child from Zagreb" which "sometimes" might be more important [ibid.: 73].

While the Zionist leadership objected to haapala (illegal immigration to Palestine), the rivaling Revisionists continued throughout the war to assist immigrants and refugees to flee Europe to Palestine. This caused Moshe Sharett, a prominent Zionist activist, to complain about the "bad human material" they were assisting: blind, crippled, and old people [ibid.: 74]. When, towards the end of the war, the Jewish Agency also began assisting with haapala, it was in order to prove the Agency had actively saved Jews. The leadership's most famous attempt at military assistance, however, was nothing but a mythologized disaster. In 1944 the Agency collaborated with the Royal Air Force in parachuting paratroopers behind enemy lines. Their main mission was to get in touch with partisans. The paratroopers were kibbutz members in their twenties: symbols of the "new Jew." They were also inexperienced and ill prepared for the mission. Expecting precise instructions from the Agency upon leaving, they received nothing more than empty slogans. "Ben-Gurion told them to act so 'the Jews would know Israel is their land and refuge,' so they would flow to it in their masses after the victory" [ibid.: 76]. The paratroopers did little more than risk their lives. Local partisans blamed them not only for not realizing the danger they were in, believing the war was just a game, but also of risking the local partisans themselves [ibid.: 76-77]. 
After the war, Zionist activists went to Europe in order to convince the survivors to immigrate to Israel. The activists were disappointed with the survivors' "hollow materialism," which they understood to be the result not only of the Holocaust, but also of their prolonged stay in exile. The activists were worried they would be useless to the Zionist cause, and were not afraid to tell them they were not the ideal "human material" [ibid.: 105-107]. Once in Israel the survivors were expected not to talk about the Holocaust. The yishuv did not want to hear about their experiences, and when survivors did tell their stories - they were not believed [ibid.: 140]. Made to keep their stories to themselves, they were alienated from the rest of society.

After years of silence, the third abuse of the elite was its instrumentalization of the Holocaust for social and political purposes. The Gruenwald-Kasztner trial in 1954-1955 deeply embarrassed the Mapai establishment. Rudolf Kasztner, a prominent member of the Histadrut, had reluctantly sued for libel the pamphleteer Malchiel Gruenwald who had accused him of collaborating with the Nazis. The trial quickly became a disturbing examination of Kasztner's, and through him of Mapai's engagement with the Nazis. The elite was understood to have wasted a precious opportunity in the flop "blood for goods" agreement, in which the Hungarian Jews would be saved in exchange for trucks and other goods supplied to the Nazis [ibid.: 78]. The trial, along with other scandals and governmental mishaps, had destabilized Ben-Gurion's and Mapai's secured status during the 1950s. For the establishment, the 1961 Eichmann trial was an opportunity not only to reaffirm its power and morality against the Kasztner affair, but also to create a new ethos for Israeli society. Observing that committed idealism was eroding among Israel's youth, Ben-Gurion saw the trial as an opportunity to induce Israeli society with new idealistic purpose and vigor [ibid.: 311-312].

The Eichmann trial was famously recounted by Hannah Arendt in Eichmann in Jerusalem, and Segev's criticism focused, similarly, on its public and political impetus, its role in raising global awareness to the Holocaust and creating a new homogenizing ethos in Israeli society. However, in spite of his criticism, Segev's description of the trial was not as critical as Arendt's. According to Segev, Arendt herself confessed to him that she had written the book in anger, and would probably have written it differently were she to write it again [ibid.: 401]. Acknowledging the trial's political purpose, Segev also noted the liberating effect the trial had had on the survivors and Israeli society. Indeed, Segev's criticisms of Zionist and Israeli history were much less vehement than other Critical Historians, and his narratives did not vilify key characters (in spite of critics' claims), but presented them as humans with strengths and weaknesses. As he wrote in the introduction to The First Israelis, "For me, the story of those first Israelis is basically one of success; I tend to think of them with compassion and not a little envy for their part in the historic task of creating a new state" [Segev 1998: v].

\section{The Palestinians}

The Critical Historians have criticized previous scholars for their depiction - or ignoring - of the Palestinians' part in the history of the Zionist movement and Israel. In previous histories, they argued, the Palestinians were either ignored, or vilified as vicious Arabs. Reconstructing the image of the Palestinians was one of the major aims of the Critical Historians, seeing that the Israeli-Palestinian conflict is one of the most central problems 
in Israeli history and society. In fact, discussing the Palestinians was a challenge in itself, as the Israeli public had been reluctant to see them as a distinct Arab people [Kimmerling - Migdal 2003: xii]. Not only did the Critical Historians have to "introduce" the Palestinians into the Israeli narrative, they also had to clearly present the Palestinian's history and identity.

\section{The Image of the Palestinian in Critical Historiography}

In spite of being sympathetic to the Palestinians, most works by the Critical Historians focused on the Palestinians from an exclusively Israeli point of view. Consequently, the Palestinians were depicted primarily as victims: massacred, deported, raped, and abused. Concerning Palestinian aggression, on the other hand, the writers usually focused on Jewish victimhood. Throughout the works of the Critical Historians there is little mention of the Palestinians as a people in itself. One reason for this may be that even the Critical Historians agreed that Palestinian national consciousness developed largely through interaction with the Zionists.

The only substantial work to treat the Palestinians from a seemingly "independent" perspective as well as to meticulously trace their origins, was Kimmerling's and Migdal's The Palestinian People from 1994. In their book, Kimmerling and Migdal claimed the Palestinians' forefathers were Bedouins who came from the Arabian Peninsula in the first half of the 7th century. Their forefathers were farmers, who nonetheless preserved their warrior identity. Their enemies were any state or authority which attempted to disarm them or restrict their movement through borders [Kimmerling - Migdal 2003: 5]. Palestinian national consciousness began to consolidate in the 19th century with the 1834 rebellion against the Ottomans. Kimmerling and Migdal followed the development of the Palestinians through their clashes and interactions with the Ottoman Empire, British rule, the Zionist movement, and finally Israeli rule. The writers generally refrained from romanticizing the history of the Palestinians as well as from sentimentality, and presented a fairly objective image of the people. Nonetheless, the book managed to enrage right wing Israelis who saw it as a radical anti-Zionist document [Gelber 2007: 416-417], and failed to satisfy Palestinian scholars, who saw it as a fundamentally orientalist work, replete with Western stereotypes [Kabha 2007: 313].

Kimmerling presented a more interesting analysis of the relations between the Palestinians and the Zionist settlers in his A Model for Analyzing Reciprocal Relations Between the Jewish and Arab Communities in Mandatory Palestine. Kimmerling analyzed the cultural, economic, and social relationships between the Zionists and the Palestinians, and showed how the interaction between the groups changed them internally. The Jews and the Arabs interacted on three levels: religious (Jewish-Muslim), cultural (Western-traditional), and political (national) [Kimmerling 2008: 8]. The political sphere of interaction was the most important, and also proved to be the most fatal for the Palestinian nation. While Jewish national consciousness was already formulated, organized, and contained a political vision, Arab-Palestinian consciousness was slow to crystalize, lacked a political vision, and was hopelessly trying to preserve the status-quo [ibid.: 10-11]. The Palestinians' failure to create a homogenous national identity was most strongly demonstrated in the 1936-1939 Arab revolt. The revolt lacked a common political and social objective, and was a mixture 
of peasant, familial, colonial, religious, class, and racial struggles [ibid.: 12]. The revolt's failure, Kimmerling asserted, foretold the Palestinians' failure during the 1948 War.

While Kimmerling's analysis was for the most part objective, it was also compassionate and empathetic towards the Palestinians. However, it suffered from one main flaw - reluctantly acknowledging the part the Zionists played in the creation of a Palestinian national identity, Kimmerling also suggested that Zionist presence in Palestine hampered Palestinian nationalism [ibid.: 13]. While he generally refrained from explicitly criticizing the Zionists (at least in works that focus on the Palestinians), it is clear that Kimmerling saw their arrival as damaging to the indigenous population, who lacked the political, cultural, social, and economic tools to deal with their sophisticated rivals.

Unlike Kimmerling, most other Critical Historians treated the Palestinians predominantly from the perspective of the Israeli-Palestinian conflict. The historians focused on the 1948 War, concentrating both on actions taken by the IDF and Jewish paramilitary organizations (Etzel and Lehi), as well as the leadership's orders during the war, and its reactions to reports of atrocities from the front. In these cases the Palestinians appear only as victims. There is hardly any mention of their lives before the war, except for the rare occasions when their peaceful or hostile relations with their Jewish neighbors are briefly mentioned. The Deir Yassin massacre, one of the most notorious symbols of Jewish violence committed by Etzel and Lehi, is a representative example of the Critical Historians' treatment of Palestinian victimhood [Morris 1999: 207-209]. In The First Israelis Segev mentioned the massacre in one sentence, only in order to explain why so many Arabs had left their villages (they were afraid of a similar fate), although he did add a footnote which briefly describes the general course of events: "Over two hundred villagers, many of them women and children, were killed. The rest were paraded through the streets of Jerusalem and then forced to cross over to the Arab part of the city. The Jewish Agency strongly denounced this action" [Segev 1998: 25]. Morris described the course of events more meticulously, recording the stages and actual acts of the massacre: "Whole families were riddled with bullets and grenade fragments and buried when houses were blown up on top of them; men, women, and children were mowed down as they emerged from houses; individuals were taken aside and shot" [Morris 1999: 208]. These descriptions, curt and to the point, are typical of the Critical Historians' depictions of the 1948 War and the Palestinians.

In other works by the Critical Historians the Palestinians were exhibited as the main victims of the Israeli-Palestinian conflict, but interest in them hardly exceeded their victimhood. Only in recent years did Pappé start writing on the conflict from a distinctively Palestinian point of view, markedly glorifying the Palestinians and vilifying the Zionists and Israelis [Morris 2004]. These attempts, however, have damaged his reputation as a credible historian, at least among Israeli and independent readers. It seems clear that for the majority of the Critical Historians, writing as Israelis meant first and foremost confronting their own history and actions.

\section{Criticizing the Critical Historians: the "Old" Historians Fight Back}

As the "old guard" of the Israeli historiography was blamed for embellishing and censoring Israeli history, renowned scholars such as Tuvia Friling, Anita Shapira, Yoav Gleber, and Shabtai Teveth found themselves compelled to defend their own research, on the one 
hand, and to counter attack the Critical Historians' works, on the other. Their criticism revolved around four main lines of argumentation: the Critical Historians interpreted events in retrospect and with knowledge that was not available to the Zionist (and later Israeli) leadership at the time; they intentionally falsified and used information out of context in order to vilify the leadership's motives; they misread sources and documents, and misunderstood the significance of events and the hierarchy of historical players [Friling 2003a: 426-427]. The fourth line of argument was directed against postmodernism in general and its imported Israeli derivative in particular [Taub 1997: 233-234].

The "clash of historians" which ensued also stirred a debate about Zionism and post-Zionism [Bar-On 2005: 53]. ${ }^{1}$ More than other points of contention, this debate quickly seeped to the media and popular discourse in Israel, diverting attention from historical facts and processes, and focusing instead on which narrative Israelis should espouse. Thus, the most noticeable impact of the Critical Historians lay not in uncovering and discussing ambivalent moments in Israeli history, but in polarizing Israeli society, leading the debate to a point in which nearly any criticism of Israeli history or politics came to be associated with post- or anti-Zionism. Soon, questions of political affinity and vision occupied the center stage, instead of historical and academic argumentation.

\section{Bending the Facts}

Several "old" historians have taken up the challenge of refuting some of the Critical Historians' claims through detailed analyses of the Critical narrative and the events as they really happened. In The Zionist Movement's March of Folly and The Seventh Million and David Ben-Gurion and the Holocaust Tuvia Friling set out to expose the techniques Segev used in The Seventh Million in order to vilify Ben-Gurion and the Zionist establishment. Friling's articles are considered milestones not only in their critique of Segev's book, but also in "exposing" the general approach and methodology of the Critical Historians.

According to Friling, Segev ignored the difficulty and complexity of the rescue operations in order to deride the Zionist establishment and its failures. Friling describes in detail all the processes and communications which surrounded these plans, in order to demonstrate that the Jewish Agency did all that could be done in order to save Jews. Friling takes up the Transnistria rescue plan as a case study. During the Second World War, Transnistria was under Romanian control. In 1941-1942 the Romanian government deported the 148,000 Bessarabian Jews to the territory. While the Romanian government did not actively exterminate the Jews deported to Transnistria, it did not provide them with any living conditions, leaving them to perish in the wilderness. In the Transnistria rescue plan, the Romanian government offered to free some 70,000 Jews who survived Transnistria in exchange for 14-28 million dollars [Segev 1991: 78]. However, both the Germans and the British objected to this deal. The Germans did not want to strengthen the Jewish settlement against their allies, the Arabs, while the British principally prohibited the entrance of citizens of enemy states into their territory. Thus the plan failed not because, but in spite

\footnotetext{
The term Post-Zionism essentially means that Zionism has finished its role in the evolution of Israel, and that Israel should (or will inevitably) become a multicultural State in which Judaism is merely one of several equal ethnicities and religions.
} 
of the Jewish Agency's efforts. However, in Segev's description of the events, he deliberates whether the Jewish Agency could not still proceed with the plan: "And thus only doubt is left if the Agency could reach an agreement with the Romanians, behind the Allies and Germans backs, in order to save several thousands; maybe it could not" [ibid.: 79]. Segev's remark, Friling claims, not only puts the blame on the Jewish Agency in spite of its efforts to save Jews, but is also absurd, given that it would be impossible to secretly transfer 70,000 people [Friling 1992: 321-322]. Friling methodically follows the failure of other rescue plans, all the while referring to Segev's narration of the same events, which belittles and disparages Ben-Gurion and the Agency's "little people" [ibid.: 321]. Instead of realizing the complexity, entanglement, and difficulty of the leadership's position, Friling claims, Segev prefers to accuse the leadership of "Palestino-centrism," pettiness, and ineffectiveness.

The Critical Historians' various theories of colonization are also strongly attacked by the "old" historians. While Zionism does exhibit some colonial characteristics as we have noted earlier, colonialism is too limited a perspective for analyzing Zionism, they claim.

The first and clearest difference is inherent in what Avi Bareli termed "forgetting Europe." By "forgetting" Europe, the Critical Historians ignore the fact that the Eastern-European Jews who immigrated to Palestine were equally "pushed" there by European antisemitism and pogroms, as much as they were "pulled" to Palestine [Bareli 2003: 304]. Moreover, the Zionists invested money in Palestine, unlike the colonialists who coveted the land's natural resources, sending them homeward [ibid. 2003: 305]. Finally, the Zionists and the Palestinians competed over labor, whereas colonialists usually exploited the indigenous population. While material analyses of Zionism as colonialism are unsatisfactory, Pappés comparison of the Zionists and the Basel Mission through the prism of discourse and consciousness is also inadequate. Pappé superficially analyzes a narrow and selective set of symbols and discourse elements, and consequently concludes that Zionism is a form of colonialism. His analysis overlooks both the material and cultural differences between the groups, and especially the role the Jews' Eastern European experience played in turning to Zionism [ibid.: 311-313].

Gelber has also exposed serious flaws in the Zionist-colonial prism, focusing on several points: 1) the Zionists did not attempt to conquer the land by force, but saw the return to manual labor as a means to "normalizing" the Jew; 2) unlike other colonialists, they attempted to create a democratic society, and sought to rely on natural growth and immigration in order to ensure their demographic majority; 3) Palestine, unlike other colonial destinations, was a poor country, its resources so scarce, both Arabs and Jews were compelled to emigrate from it during the waning of the Ottoman Empire; 4) while colonialists took over land and resources by force, the Zionists purchased land, causing land prices to rise; 5) the Zionists did not attempt to take over the existing Arab economy, but actually competed with the Arabs over the labor market; 6) culturally, the Zionists severed ties with the "old" world, seeking to create a new society; 7) finally, in Palestine the Zionists sought to revive an ancient heritage, as can be seen in the use of the Hebrew language - in other words, theirs was a typical 19th century national revival, and not a colonialist effort [Gelber 2007: 416-421].

Gelber's arguments are convincing for the main part, though they are based on general statements, and sometimes lack scientific accuracy and detail. His attempt to revoke all postcolonial arguments in a few pages is bound to remain incomplete and defective. His 
claim, for example, that unlike other colonialists the Zionists did not use force in conquering the land [ibid.: 418], is true, but this was not necessarily out of goodwill as out of lack of military ability. In 1904 Menachem Ussishkin, a leader of the Zionist group Hovevei Zion wrote: "[W]ithout ownership of the land, Erez Yisrael will never become Jewish. [Land is acquired in the modern world by three methods]: by force - that is, by conquest in war, or in other words, by robbing land from its owner; [...] by expropriation via governmental authority; or by purchase [...] we are too weak, therefore, we have but the second and third [options]" [quoted in: Morris 1999: 38]. Ussishkin and other Zionist activists acknowledged their military weakness on the one hand, and their economic strength on the other, and hardly used moral arguments in preferring purchase over violence.

\section{Conclusion}

Criticizing the Critical Historians has focused therefore mostly on their selective representation of facts and events. Philosophy professor Elhana Yakira has controversially compared this technique to the one used by Holocaust deniers [Yakira 2006]. While Yakira's comparison is generally accepted to be an exaggeration, the Critical Histories are not free from misrepresentations, as Moshe Zimmermann, a vocal critique of Israel, has had to admit, at least in relation to The Seventh Million [Friling 2003a: fn. 66]. However, it is impossible to claim the Critical Historians' works are entirely fictitious and unreliable. Not devoid of mistakes and political motivation, not only did they bring new unknown facts to the center of attention, they have managed to stir a serious debate on Israeli history, shattering the previous view of Israel as "pure" and completely just. Many of the Critical Historians have also revised their works, acknowledged their mistakes, and published new works which substantiate their claims. Seeing that the historical and sociological discourse in Israel is predominantly modernistic, the Critical Historians have had to base their research on "dry" facts, more than anything else. The interpretation and arrangement of facts are indeed in the hands of the writer, but it cannot be said all Critical Historians have taken more liberty with them than the "old" historians. The main difference between the "old" and Critical historians is essentially in the party with which the writers identify. While the "old" historians see themselves as Zionists, and identify with the history of Zionism, in spite of its faults and wrongs, the Critical Historians are not necessarily Zionist, and are consequently less empathetic towards the Zionists and their actions. As Anita Shapira has noted, the Critical Historians were less immersed in the exhilaration of building Israel than the "old" historians were, but this was less a result of generational gaps, as she has claimed, and probably more a result of a collective discomfort with the path Israel was taking in the 1980s and the intensification of the crisis it was in.

\section{Bibliography}

Bareli, Avi [2003]. Forgetting Europe: Perspectives on the Debate about Zionism and Colonialism. In. Friling, Tuvia (ed.). An Answer to a Post-Zionist Colleague. Tel Aviv: Yedioth Ahronoth, pp. 294-317. (Hebrew).

Bar-On, Mordechai [2005]. What Happened to the "New History" in the Turn of the Century. Iyunim Bitkumat Israel 15: 53-81. (Hebrew). 
Friling, Tuvia [1992]. The Zionist Movement's March of Folly and The Seventh Million. Iyunim Bitkumat Israel 2: 317-367. (Hebrew).

Friling, Tuvia [2003]. Maturation Processes in a Fissured Identity. In. Friling, Tuvia (ed.). An Answer to a Post-Zionist Colleague. Tel Aviv: Yedioth Ahronoth, pp. 13-62. (Hebrew).

Friling, Tuvia [2003a]. David Ben-Gurion and the Holocaust. In. Friling, Tuvia (ed.). An Answer to a Post-Zionist Colleague. Tel Aviv: Yedioth Ahronoth, pp. 418-456. (Hebrew).

Gelber, Yoav [2007]. History, Memory and Propaganda. Tel Aviv: Am-Oved. (Hebrew).

Gutwein, Daniel [2003]. Postzionism, the Privatization Revolution and the Social Left. In. Friling, Tuvia (ed.). An Answer to a Post-Zionist Colleague. Tel Aviv: Yedioth Ahronoth, pp. 243-273. (Hebrew).

Kabha, Mustafa [2007]. A Palestinian Look at the New Historians and Post-Zionism in Israel. In. Morris, Benny (ed.). Making Israel. Ann Arbor: University of Michigan Press, pp. 299-316.

Kimmerling, Baruch [2001]. The End of Ashkenazi Hegemony. Jerusalem: Keter. (Hebrew).

Kimmerling, Baruch [2001a]. The Invention and Decline of Israeliness. University of California Press.

Kimmerling, Baruch [2008]. Clash of identities: explorations in Israeli and Palestinian societies. Columbia University Press.

Kimmerling, Baruch, - Migdal, Joel S. [2003]. The Palestinian People. Harvard University Press.

Lissak, Moshe [2007]. "Critical" and "Establishment" Sociology in Israel's Academic Community. In. Morris, Benny (ed.). Making Israel. Ann Arbor: University of Michigan Press, pp. 178-201.

Morris, Benny [1999]. Righteous Victims. New York: Knopf.

Morris, Benny [2004]. Politics by Other Means. [online]. New Republic. Accessed: <https://newrepublic .com/article/61715/politics-other-means-0> [20.5.2016].

Morris, Benny [2007]. The New Historiography: Israel Confronts Its Past. In. Morris, Benny (ed.). Making Israel. Ann Arbor: University of Michigan Press, pp. 11-28.

Pappé, Ilan [1997]. Zionism as Colonialism. In. Weitz, Yechiam (ed.). Jerusalem: The Zalman Shazar Center for Jewish History, pp. 345-366. (Hebrew).

Ram, Uri [1993]. Society and the Science of Society: Mainstream and Critical Sociology in Israel. In. Ram, Uri (ed.). Israeli Society: Critical Perspectives. Tel Aviv: Breirot, pp. 7-39. (Hebrew).

Ram, Uri [1996]. Memory and Identity: Sociology of the Historians' Debate in Israel. Theory and Criticism 8: 9-32. (Hebrew).

Ram, Uri [1997]. Zionist and Post-Zionist Historical Consciousness in Israel: A Sociological Analysis of the Historians' Debate. In. Weitz, Yechiam (ed.). Zionist Historiography Between Vision and Revision. Jerusalem: The Zalman Shazar Center for Jewish History, pp. 275-289. (Hebrew).

Ram, Uri [2006]. The Time of the "Post". Theory and Criticism 26: 241-254. (Hebrew).

Raz-Krakotzkin, Amnon [1993]. Exile within Sovereignty: Toward a Critique of the "Negation of Exile" in Israeli Culture, part 1\&2. Theory and Criticism 4: 23-55; Theory and Criticism 5: 113-132.

Segev, Tom [1991]. The Seventh Million: Israelis and the Holocaust. Jerusalem: Keter Publishing House. (Hebrew).

Segev, Tom [1998]. 1949: The First Israelis. New York: The Free Press. (Hebrew: 1987).

Segev, Tom [2001]. The New Zionists. Jerusalem: Keter. (Hebrew).

Shafir, Gershon [1993]. Land, Labor, and Population in Zionist Colonization: General and Unique Aspects. Ram, Uri (ed.). Israeli Society: Critical Perspectives, Tel Aviv: Breirot, pp. 104-119. (Hebrew).

Taub, Gadi [1997]. A Dispirited Rebellion: Essays on Contemporary Israeli Culture. Tel Aviv: Hakibbutz Hameuchad. (Hebrew).

Adam Coman is a writer and PhD student in the Historical Sociology department at Charles University. He has published one novel in Hebrew The Sound of Many Tiny Feet Angrily Stomping the Face of the Earth, and short works in Israeli newspapers and journals. 